\title{
Analysis of Development of Innovation and Competitiveness in Montenegro
}

\author{
Zdravko Krivokapić, Jelena Jovanović, Aleksandar Vujović \\ Faculty of Mechanical Engineering Podgorica, Montenegro \\ Sanja Peković \\ Faculty of Tourism and Hotel Management, Montenegro \\ Davorin Kramar \\ Faculty of Mechanical Engineering Ljubljana, Slovenia
}

\section{Abstract}

This paper presents some of the results obtained during many years of work on the scientific - research projects in the field of innovation and improvement of organizational performance with aim to find an answer about Capacity for innovation of Montenegrin organizations. The paper is based on the unique database which reflects the real conditions of the Montenegrin organizations. In the paper is also analyzed report prepared by World Economic Forum (WEF) for 20142015 years about Global Competitiveness Index (GCl) for Montenegro. In accordance with that report and analysis of survey performed in Montenegrin organizations carried out by interview method, authors of the paper tried to give an answer about Capacity for innovation in Montenegro. Based on that analysis we found that Montenegrin organizations are focused on innovation but there still have a lot of spaces for improving in order to achieve higher level of Global Competitiveness Index.

Keywords: Innovations, Capacity for innovation, GCl, Questionnaire JEL classification: 031

\section{Introduction}

During the last few years and especially strengthen by the most recent crisis, the model of economic development based on competition and innovation becomes more important. Innovativeness represents a necessary condition for revitalization in cases of the decline in indicators of business success. If they want to survive and dominate in domestic and global economic market, business systems need to follow the changes, it is no longer sufficient to keep pace with them, but often to be a step ahead (Leydesdorff, 1998; Porter, 2001).Organizations that learn, in which people continuously expand their capacity to create results, have the highest chances for success and progress in future. Ability to learn faster than competition can be one sustainable competitive advantage in today's business environment (Davila, 2006).

These trends, and the importance of the innovation and competitiveness in organization, gave an impetus to the authors of this study to carry out an analysis of innovation in Montenegro from the point of view report of Global Competitiveness Index for Montenegro (period 2014-2015) prepared by World Economic Forum (WEF). Global Competitiveness Index is based on 12 pillars and a specific attention in the paper is focused on the $12^{\text {th }}$ pillar, called Innovation. 


\section{Innovation}

Innovation is introduction of a new, previously unknown product or process or significant improvement of already existing organization scheme which leads to the development of a new generation of products and their distribution.Business system that tends to be successful and to make a progress in market aspect needs to be innovative. Creation of the new market or new category of product is the most efficient way of competing in mature markets. Innovations and innovative strategies, constant improvements and application of knowledge bring a series of advantages and their significance is reflected in the following (Pavitt, 2000; Casadesus, 2008; Bossink, 2002):

- Innovation encourages the economic growth and makes profit,

- Growth in innovations of $1 \%$ contributes to the growth of income per a citizen of about $0,05 \%$,

- Innovation directly influences the increase of employment and indirectly contributes to economic efficiency and profit,

- Innovative products provide the winning and retaining of a share in the market, as well as the increase of profitability in markets.

The concept of innovation can best be observed through the definition of innovation as the implementation of a new and improved idea, procedure, good, service, process which brings new benefits or quality in implementation.

\section{Global competitiveness index}

In past few decades, the World Economic Forum (WEF) is ranked as the most important institution which affirmed the problem of measuring the competitiveness of the national system. Since 2004, WEF, based on annual review and the methodology improvement for assessing competitiveness, introduced the Global Competitiveness Index (GCl), which is determined by weighting the average of 12 pillars of competitiveness, organized into three parts that are key to the different ways of managing the national economy. From the figure 1 we can see that all 12 pillars are divided into 3 groups of keys for driven economy, as following:

1) Keys for factor - driven economy

2) Keys for efficiency - driven economy

3) Keys for innovation-driven economy

The most important topic, from the point of this paper, is focused on innovation and keys for innovation driven economy. As we can see two pillars important for innovation driven economy are:

- business sophistication and

- Innovation.

Business sophistication is a topic which can be analyzed in comparison with developed countries based on statistical data about type of organizations and their main activities. It can be realized by public body who is involved in operation with statistical data about enterprises which means that Business sophistication can be exactly defined.In the other hand, pillar 12th, focused on innovation is not easy for definition. In accordance with that and with the fact that innovation is a very important pillar for innovation driven economies we are focused our attention on that pillar. 
Figure 1

The 12 Pillars of Competitiveness According Global Competitiveness Index

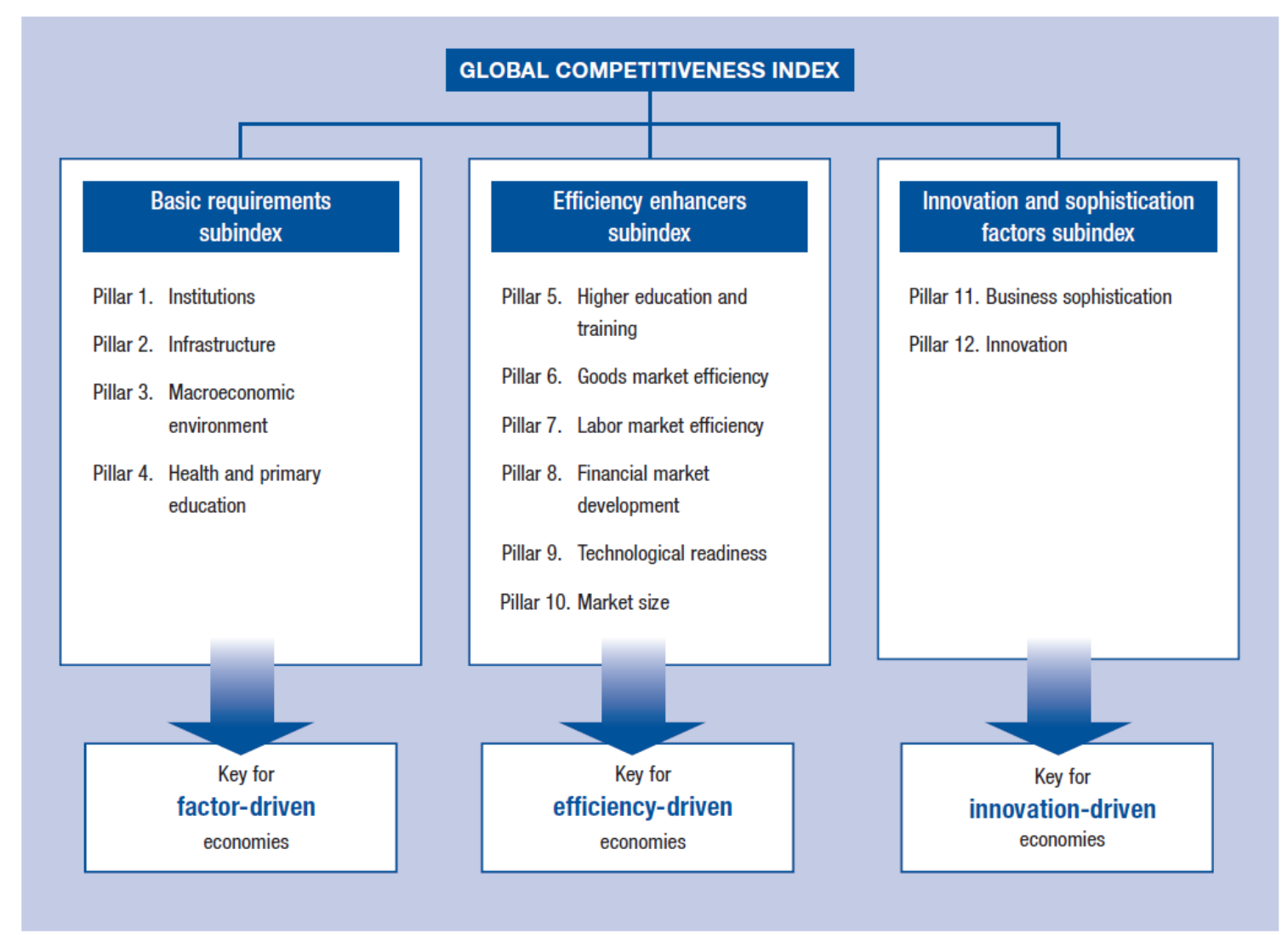

Source: http://reports.weforum.org/global-competitiveness-report-2014-2015/

In the figure 2 are presented results of state of innovation in Montenegro for 20142015 years, based on the research of World Economic Forum. We can see from the figure 2 that result about Capacity of innovation is the worst because in accordance with that the Montenegro is on the 84 stage of rank in competition with 144 countries. Based on literature sources we found that the factors of Innovation system are:

- State administration

- Local administration and

- Organizations.

In accordance with that, we can say that the most important factor for Innovation system, where can be created well capacity for innovation, are organizations.

The capacity of firms and people of a nation to steadily achieve innovations in the context of changing production and market conditions is designated as innovative capacity (Belitz, 2006). 
Figure 2

State of Innovation in Montenegro

Stage of development

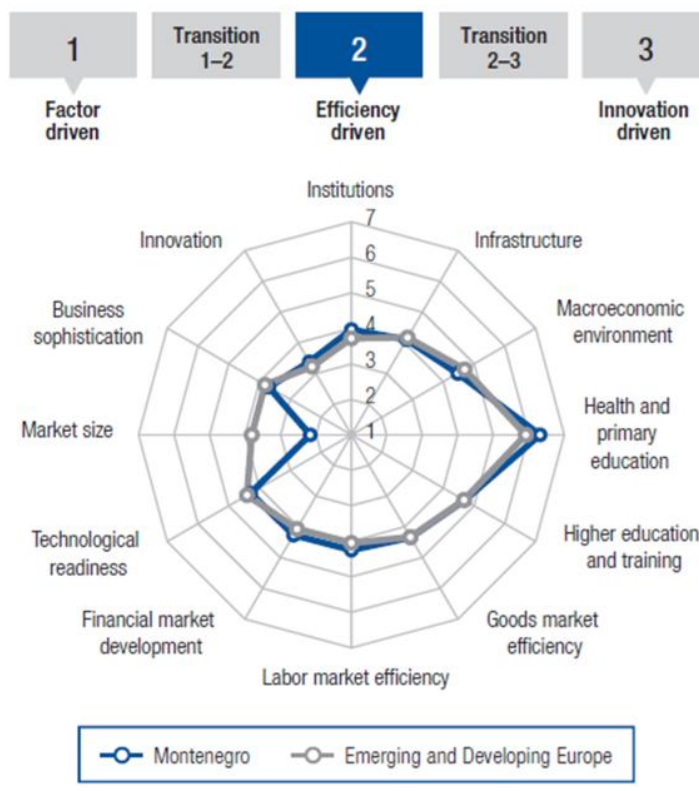

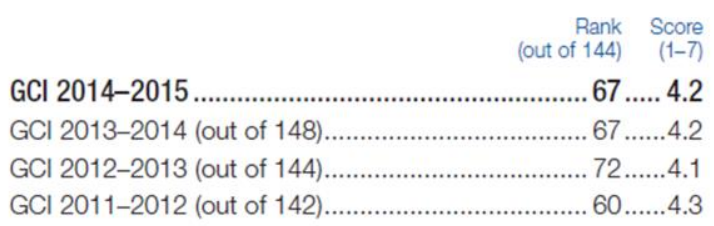

12th pillar: Innovation

12.01 Capacity for innovation......................................... 3.6... 84

12.02 Quality of scientific research institutions ............. 3.9....60

12.03 Company spending on R\&D.............................. 3.2 ....61

12.04 University-industry collaboration in R\&D ............. 3.9.... 47

12.05 Gov't procurement of advanced tech products.. 3.6 ... 57

12.06 Availability of scientists and engineers ................ 4.1...69

12.07 PCT patents, applications/million pop. *.............. 3.2 .... 51

Source: http://reports.weforum.org/global-competitiveness-report-2014-2015/

\section{Research methodology and results}

Research was carried out by interview method. Questionnaire that is used in that occasion consisted of 91 questions, 33 of which referred to innovativeness. From the set of all Montenegrin business systems, we performed a survey on the sample of 120 business systems. For the purpose of this study a comparison was based on seven issues, which the authors believe that in terms of the goals are the most important and can contribute to obtaining the most beneficial results (Krivokapic, 2012, 2014). The following table gives a comparative view on all items.

In the Table 1 are presented results of investment in modernization of business system in Montenegro in the last 3 years. As we can see, most of surveyed organizations said that have investments in the business system modernization.

Table 1

Investment in modernization of business systems

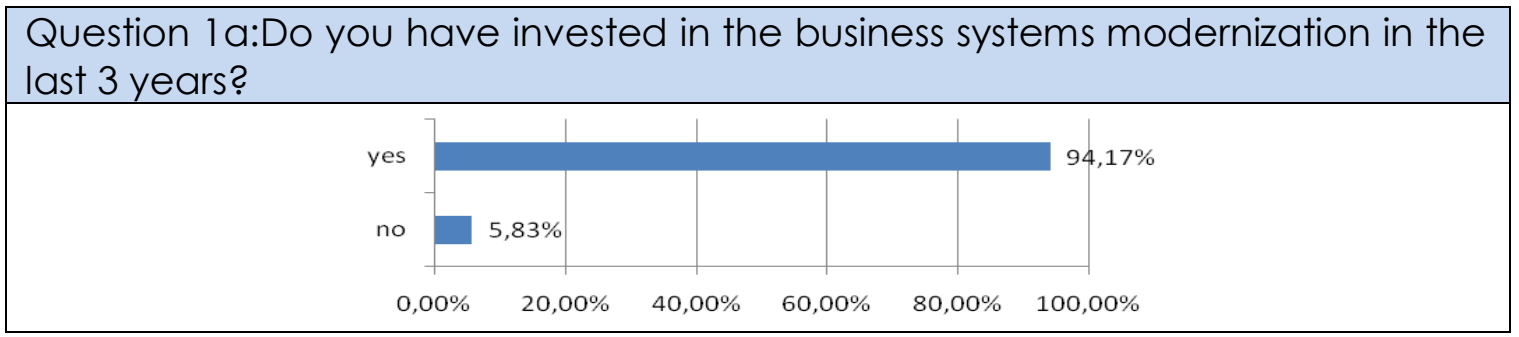

Source: Author's table

In the Table 2 are presented results about person or team responsible for innovation in Montenegrin organizations. We found that more than $50 \%$ of surveyed organization does not have person or team responsible for innovation. 
Table 2

The existence of the person or team responsible for innovation

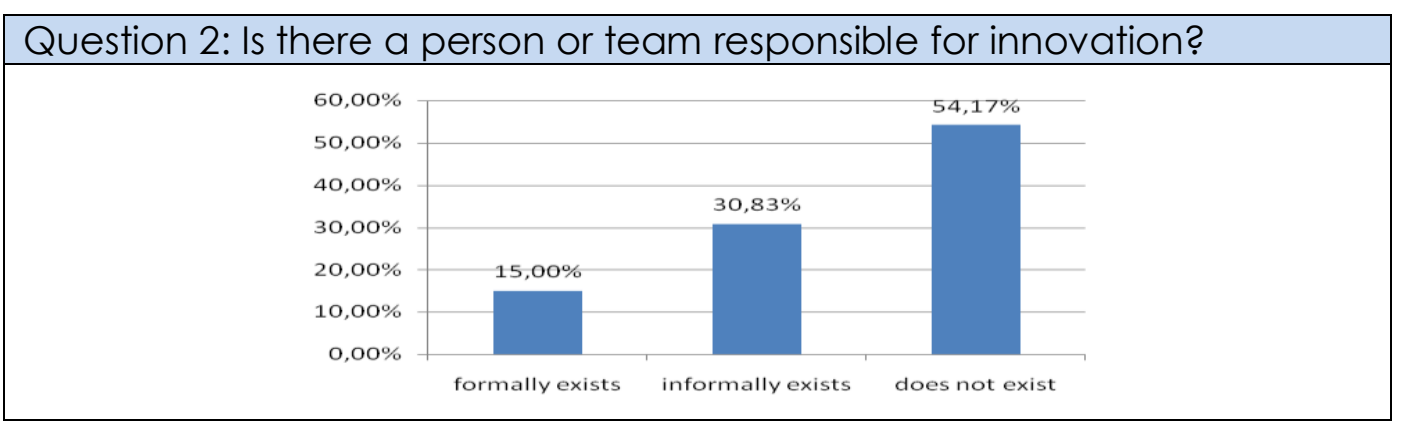

Source: Author's table

We also tried to find an answer about frequency of meetings which are focused on innovations in Montenegrin organizations. We can see in Table 3 that 35,84 of surveyed organizations doesn't have meetings focused on innovations.

Table 3

The frequency of innovation related meetings

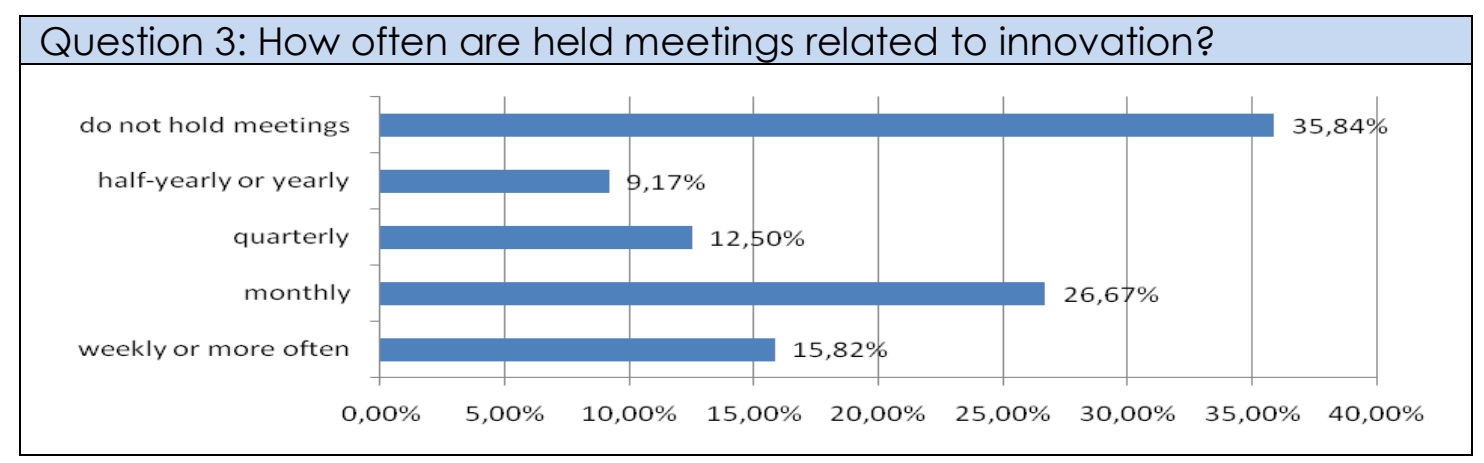

Source: Author's table

Results of survey focused on funds allocated for innovation are presented in Table 4. We can see that 31,64\% Montenegrin organizations doesn't set aside funds for innovations.

Table 4

The funds allocated to innovation

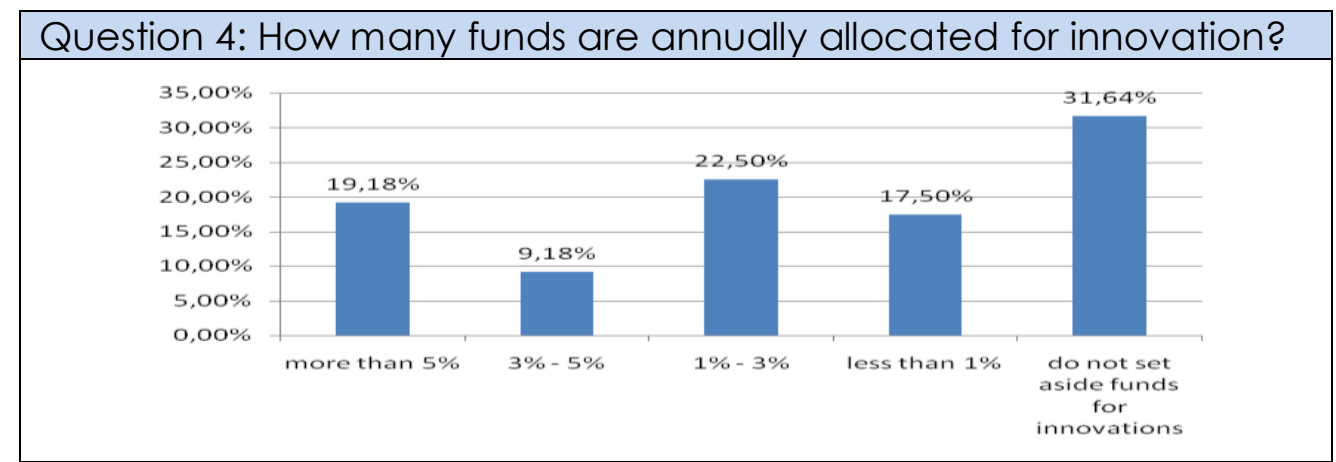

Source: Author's table

In the Table 5 is presented results about Place of innovation in the strategy of the operating system in Montenegrin organizations.

Table 5 
Place of innovation in the strategy of the operating system

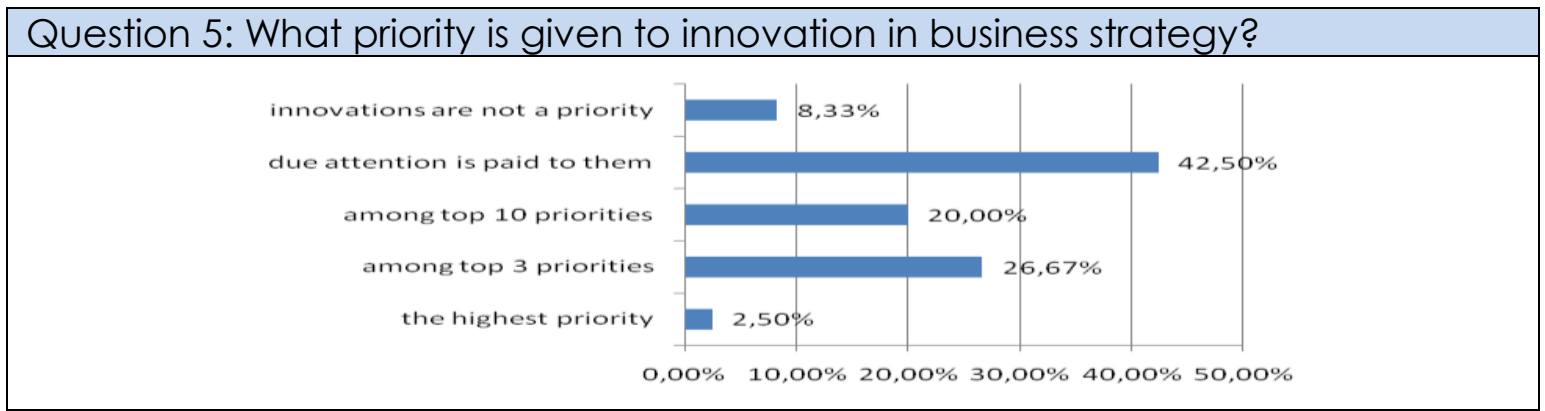

Source: Author's table

When we analyzed are there any documents that include innovation in surveyed Montenegrin organizations, we found that 33,99\% of surveyed organizations don't include innovativeness in their documents.

\section{Table 6}

Documents that include innovation

\section{Question 6: Documents that involve innovation?}

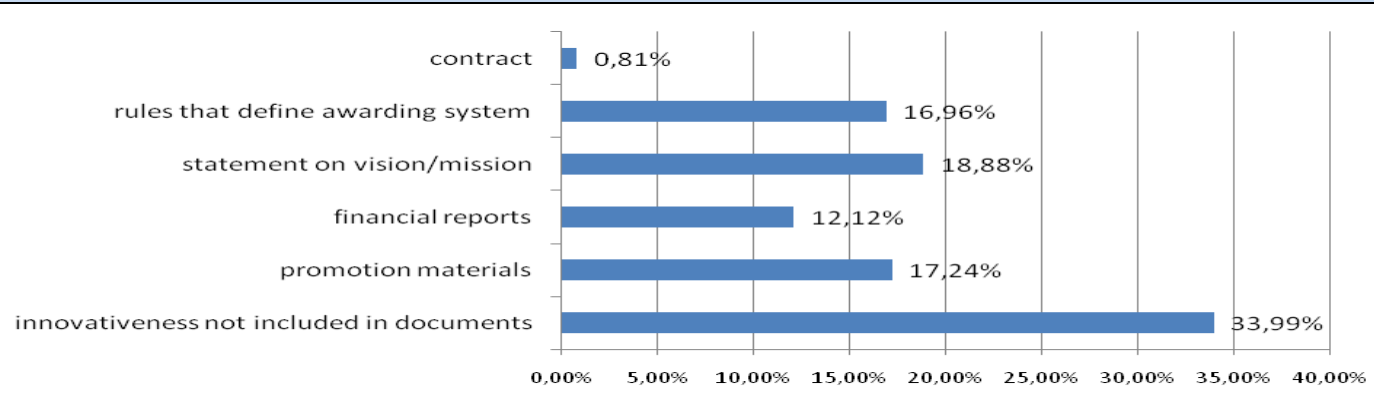

Source: Author's table

In the Table 7 is presented analysis of share of revenues from innovation in the total income of business systems in last 3 years in surveyed Montenegrin organizations.

Table 7

Share of innovation in the total income of business systems

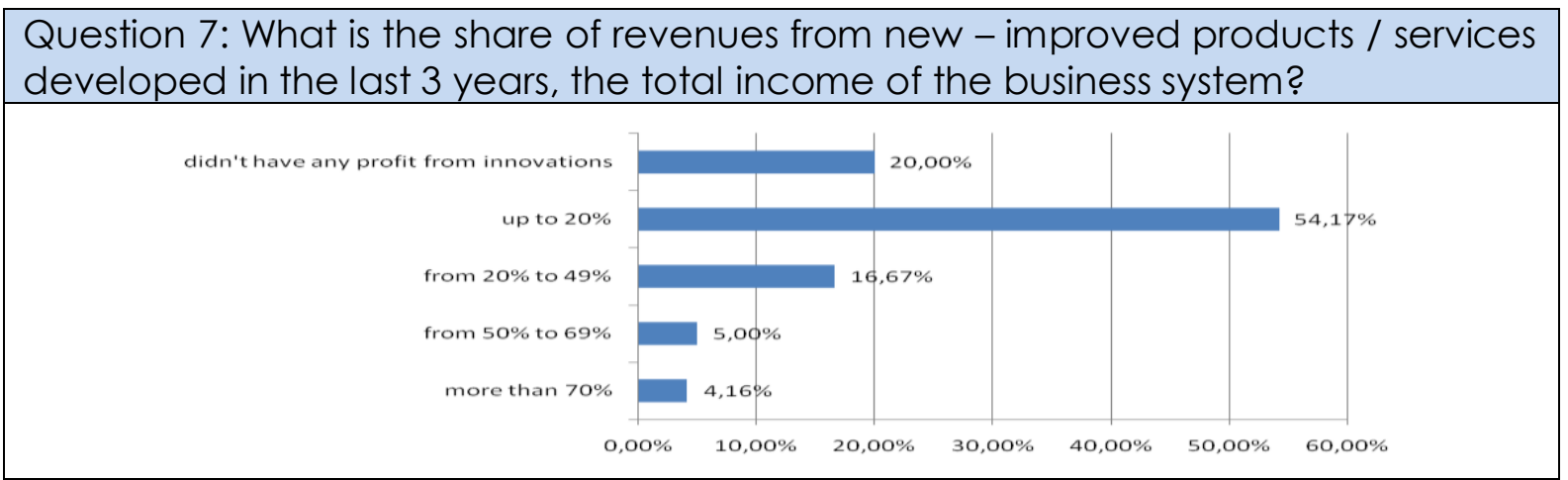

Source: Author's table

With this defined results and views, we enter into the analysis and conclusions presented in the next section work. 


\section{Conclusion}

We performed a survey in 120 Montenegrin organizations and found that there are a lot of fields for improving its innovation. Based on that survey we found that even, organizations invested in the modernization of their business system (mostly in equipment), most of them don't have person or team responsible for innovation.Most organizations allocated less than $5 \%$ of funds per year to the innovation while just $19,18 \%$ allocated more than $5 \%$. The very serious fact is that more than $30 \%$ organizations don't allocate any funds for innovation. There were also found that innovation is important for organizations but they mostly don't include innovation in their documents.Based on this survey we found that it is not so bad situation in Montenegrin organizations in relation to innovation but there still have a lot of spaces for improving in order to achieve higher level of Global Competitiveness Index. However, increasing the innovation capacity and improving business processes innovation system, create a predisposition for the development of a number of new products / services, and thus greater chance of their commercialization. In order to improve innovation in organizations they need to: develop a strategy for the company which will be an integral part of innovation activities and to develop organizational structures and processes that support innovation activities. Having in mind that sample for the research is just 120 organizations it is necessary to expand it in order to have a more objective and reliable results. In the future work we plan to expand the sample for research and to analyze which type of Montenegrin organizations (production or service) has a higher capacity for innovations.

\section{References}

1. Belitz H., Werwatz A. (2006), "Capacity for Innovation: Among Leading Industrial Countries, Germany only Manages a Middle Rank", German Institute for Economic Research (DIW Berlin), Vol. 2 No. 1, pp. 1-10.

2. Bossink B.A.G. (2002), "The strategic function of quality in the management of innovation", Total Quality Management, Vol. 13, No. 2.

3. Casadesus M., Castillo S.M., Karapetrović S., Heros I., Martin I. (2008), "Do Standardized Management Systems Hinder Innovation Processes", International Journal for Quality research, Vol. 2 No. 2, pp. $121-127$.

4. Davila T., Epstein M.J., Shelton R. (2006), "Making Innovation Work - How to Manage It, Measure It, and Profit from It", Wharton School Publishing.

5. Krivokapic Z., Crnogorac O., Vujovic A., Petrovic S., Jovanovic J. (2014), "Comparative Analysis Of Innovation Performance In Certified Firms In Montenegro And Republic Of Srpska", International Journal for Quality Research, Vol. 8 No. 1, pp. 1-8.

6. Krivokapic Z., Vujovic A., Petrovic S., Jovanovic J., Pekovic S. (2012), "Research results of innovativeness in certified business systems", Proceeding of 6th International quality conference, 07-09 June 2012, Kragujevac, pp. 9-13.

7. Krivokapic Z., Vujovic A., Petrovic S. (2012), "Značaj inovacija u sertifikovanim poslovnim sistemima", Časopis kvalitet\&izvrsnost, Vol. 1-2, pp. 31-33.

8. Leydesdorff L., Etzkowitz H. (1998), "The triple helix as a model for innovation studies", Science \& Public Policy.

9. Pavitt K. (2000), "Technology, Management and Systems of Innovation", Edward Elgar, Cheltenham.

10. Porter M.E., Stern, S. (2001), "Nacional Innovative Capacity", In the Global Competitivenes Report 2001-2002, World Economic Forum, Oxford University Press, New York.

11. World Economic Forum (2014), "The Global Competitiveness Report 2014-2015", available at: http://reports.weforum.org/global-competitiveness-report-2014-2015/ (accessed April 30 th 2015) 


\section{About the authors}

Zdravko Krivokapic is Doctor of Philosophy - Doctor of Science in Engineering from the Faculty of Mechanical Engineering. He is Full professor at University of Montenegro. Actively works with quality, quality management system, quality of education, informatics and accreditation. He is President of Board of Accreditation Body of Montenegro. He is member of Board for establishment and improvement of quality system of University of Montenegro. He is a president of national Conference of Quality (SQM) and International Quality Conference (ICQME). He is editor of International Journal for Quality Research. Author can be contacted at zdravkok@ac.me

Dr Jelena Jovanovic has Ph.D. at the Faculty of Mechanical Engineering Podgorica. She is Assistant Professor at the University of Montenegro. Her research interests are within the fields of Managements System standards and Performance Management System. She was consultant in more than 15 projects related to Management Systemsimplementation according ISO 9001, ISO 14001, ISO 17025, ISO 17020 standards and HACCP. She was engaged in many scientific research projects. She published more than 40 articles in international journals and international conferences and more than 50 articles in national journals and national conferences. Author can be contacted at sjelena@-com.me

Aleksandar J. Vujovic, graduated at the Faculty of Mechanical Engineering in Podgorica in 2000, at Department of Production Engineering. Master's thesis entitled "Nonconformity macro control models as a basis for improving the QMS", defended at the Faculty of Mechanical Engineering in Podgorica in 2004. He earned his doctorate at the Faculty of Mechanical Engineering in Podgorica in 2008. For his doctoral dissertation was awarded with the "Trimo". From 2000 to 2008 he worked as a teaching assistant, when he became a professor of: industrial engineering, flexible manufacturing systems, integrated systems management expertise and laboratory practice. Author can be contacted at aleksv@ac.me

Dr Sanja Pekovic has a Ph.D. in Economics from the University Paris-EST. She is Assistant Professor at the University of Montenegro. Between 2006 and 201 1, she was Researcher at the Center for Labor Studies (Centre d'Eudes de l'Emploi) and Lecturer at the University Paris-EST. In 2006, she obtained a Master's degree from the Ecole Nationale Des Pontset Chaussées and University of Paris-EST Marne-la-Vallée. Her research interests are within the field of quality and environmental economics, economics of innovation, applied econometrics, and on this topic she has published in international journals. Author can be contacted at psanja@ac.me

Davorin Kramar is an Assistant Professor at the Faculty of Mechanical Engineering, University of Ljubljana in Slovenia. He received PhD degree at the same university in the field of combining non-conventional and classical manufacturing technologies. His research interests refer to removal mechanisms and machinability of hard-tomachine materials such as stainless steels, hardened steel, and super alloys, etc. using high pressure assisted turning. The latest researches encompass manufacturingprocesses control, modelling and optimization of process parameters, monitoring and identification of processes, process optimization... Author can be contacted at davorin.kramar@fs.uni-lj.si 